\title{
HUBUNGAN KUALITAS PELAYANAN DENGAN KEPUASAN MASYARAKAT PENGGUNA BUS RAPID TRANSIT (BRT) MAMINASATA
}

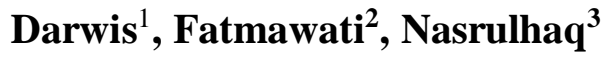 \\ 1) Jurusan Ilmu Administrasi Negara Fisipol Unismuh Makassar \\ 2) Jurusan Ilmu Administrasi Negara Fisipol Unismuh Makassar \\ 3) Jurusan Ilmu Administrasi Negara Fisipol Unismuh Makassar
}

\begin{abstract}
The aims of this research was to determine the correlation of service quality to the public satisfaction of using Bus Rapid Transit (BRT)Maminasata. This research used quantitative deskriptive type of observational (non-experimental) with cross section, and then analyzed with descriptive and inferential statistic. Data Analysis techniques was used by SPSS. The population amount from this sample is 561 passengers and 101 of them is passengers. The result of this research showed that the respondents receive good quality service from Damri Corporation as operator Bus Rapid Transit (BRT) Maminasata has value 75.51. The people feel very satisfied with the services of Bus Rapid Transit (BRT) Maminasata, it is showed the value 80.27. and then the result correlation test of product moment with significant value 5\% showed there were strong correlation between quality service with public satisfaction of using Bus Rapid Transit (BRT) maminasata has Value 0.606.
\end{abstract}

Keywords: Service Quality, Public Satisfaction, and Bus Rapid Transit (BRT) Maminasata.

\begin{abstract}
ABSTRAK
Penelitian ini bertujuan untuk mengetahui hubungan kualitas pelayanan dengan kepuasan masyarakat pengguna Bus Rapid Transit (BRT) Maminasata. Penelitian ini menggunakan deskriptif kuantitatif dengan tipe penelitian observasional (non-eksperimen) dengan pendekatan cross section, kemudian dianalisis dengan statistik deskriptif dan inferensial. Teknik analisis data yang digunakan melalui program SPSS. Populasi daalam penelitian ini yaitu sebanyak 561 penumpang dan sampel penelitian sebanyak 101 penumpang. Hasil dari penelitian ini menunjukkan bahwa responden mendapat pelayanan yang berkualitas dari Perum Damri sebagai operator Bus Rapid Transit (BRT) Maminasata dengan nilai yaitu mencapai 75.51. Masyarakat merasa sangat puas atas pelayanan Bus Rpid Transit (BRT) Maminasata, hal ini terlihat dari nilai kepuasan mencapai 80.27. kemudian dari hasil uji korelasi product moment dengan signifikan 5\% menunjukkan adanya hubungan yang kuat antara kualitas pelayanan dengan kepuasan masyarakat pengguna Bus Rpid Transit (BRT) Maminasata yaitu mencapai 0.606.
\end{abstract}

Kata Kunci : Kualitas Pelayanan, Kepuasan Masyarakat, dan Bus Rpid Transit (BRT) Maminasata. 
PENDAHULUAN

Pelayanan publik merupakan salah satu tugas utama dari negara dalam memberi pelayanan kepada masyarakat baik dalam bentuk jasa maupun fasilitas. Bahkan untuk mengukur tingkat kemajuan sebuah negara, kualitas pelayanan publik dapat digunakan sebagai salah satu indikator dalam penilaiannya. Kepuasan dan perhatian terhadap kualitas jasa/layanan pertama kali diperkenalkan oleh Gronroos dalam Tjiptono (2005:45) melalui konsep perceived service quality dan model kualitas jasa total.

\section{Menurut Parasuraman} (2001:162) bahwa konsep kualitas layanan yang diharapkan, dirasakan dan ditentukan oleh kualitas layanan. Kualitas layanan tersebut terdiri dari daya tanggap, jaminan, bukti fisik, empati dan kehandalan.Salah satu tolok ukur untuk mengetahui tingkat kualitas pelayanan publik yaitu dengan adanya kepuasan masyarakat. Kepuasan masyarakat merupakan faktor yang sangat penting dan menentukan keberhasilan penyelenggaraan pelayanan publik karena masyarakat adalah konsumen dari produk yang dihasilkannya. Oleh karena itu, penyelenggara pelayanan publik harus dapat memenuhi kebutuhan dan keinginan masyarakat sehingga mencapai kepuasan masyarakat dan lebih jauh lagi kedepannya dapat dicapai kesetiaan masyarakat.Salah satu permasalahan dan perlu adanya peningkatan dalam kualitas pelayanannya adalah di bidang jasa transportasi.

Beach dan Bushirle dalam Amalina (2010: 24) mengatakan bahwa kualitas pelayanan dapat dipengaruhi oleh beberapa faktor yaitu Penampilan, Keahlian, Suara dan kebiasaan di dalam bekerja, Tata cara dan tingkah laku.

Agar pelayanan yang diberikan berkualitas tentu saja kedua kualitas yang dimaksud harus terpenuhi. Secara terinci master dalam Sinambela (2011:7) mengemukakan berbagai hambatan 
dalam pengembangan sistem manajemen kualitas, antara lain: (1) Ketiadaan komitmen pada manajemen, (2) Ketiadaan pengetahuan dan kekurang pahaman tentang manajemen kualitas bagi aparatur yang bertugas melayani, (3) Ketidakmampuan aparatur mengubah kultur yang mempengaruhi kualitas manajamen pelayanan pelanggan,

Ketidaktepatan perencanaan manajemen kualitas yang dijadikan pedoman dalam pelayanan pelanggan, (5) Pendidikan dan pelatihan yang berkelanjutan belum dioptimalkan, (6) Ketidakmampuan membangun learning organization, learning by the individuals dalam organisasi, (7) Ketidaksesuaian antara struktur organisasi dengan kebutuhan, (8) Ketidakcukupan sumberdaya dan dana, (9) Ketidaktepatan sistem penghargaan dan balas jasa bagi karyawan, (10) Ketidaktepatan mengadopsi prinsip manajemen ke dalam kualitas organisasi, (11) Ketidaktepatan dalm memberikan perhatian pada pelanggan, baik internal maupun eksternal, dan (12) Ketidaktepatan dalam pemberdayaan dan kerjasama.

Menurut Selnes dalam Fardhani (2010:17), kepuasan masyarakat mencakup tingkat kepuasan secara keseluruhan (overallsatisfaction), kesesuaian pelayanan dengan harapan masyarakat (expectation), dan tingkat kepuasan masyarakat selama menjalin hubungan dengan instansi (experience). Adapun faktor yang mempengaruhi kepuasan masyarakat yang dikemukakan oleh Fitriani (2014: 34) yaitu: (1) Mutu produk, (2) Harga, (3) Service Quality (Servqual), dan (4) Emotional factor. Indikator kepuasan masyarakat menurut Kepmenpan No.25 Tahun 2004 terdiri dari 14 unsur, yaitu: (1) Prosedur pelayanan, yaitu kemudahan tahapan pelayanan yang diberikan pada masyarakat dilihat dari sisi kesederhanaan alur pelayanan, (2) Persyaratan pelayanan, yaitu persyaratan teknis dan administratif yang diperlukan untuk mendapatkan pelayanan sesuai dengan jenis pelayanannya, (3) Kejelasan petugas pelayanan, yaitu keberadaan dan kepastian petugas 
yang memberikan pelayanan (nama, jabatan serta kewenangan dan tanggung jawabnya),

Kedisiplinan petugas pelayanan, yaitu kesungguhan petugas dalam memberikan pelayanan terutama terhadap konsistensi waktu kerja sesuai ketentuan yang berlaku, (5) Tanggung jawab petugas pelayanan, yaitu kejelasan wewenang dan tanggung jawab petugas dalam penyelenggaraan dan penyelesaian pelayanan, (6) Kemampuan petugas pelayanan, yaitu tingkat kemampuan dan keterampilan yang dimiliki petugas dalam memberikan/ menyelesaikan pelayanan kepada masyarakat, (7) Kecepatan pelayanan, yaitu target waktu pelayanan dapat diselesaikan dalam waktu yang telah ditentukan oleh unit penyelenggara pelayanan, (8) Keadilan mendapatkan pelayanan, yaitu pelaksanaan pelayanan dengan tidak membedakan golongan/ status masyarakat yang dilayani,

Kesopanan dan keramahan petugas, yaitu sikap dan perilaku petugas dalam memberikan pelayanan kepada masyarakat secara sopan dan ramah serta saling menghargai dan menghormati, (10) Kewajaran biaya pelayanan, yaitu keterjangkauan masyarakat terhadap besarnya biaya yang ditetapkan oleh unit pelayanan, (11) Kepastian biaya pelayanan, yaitu kesesuaian antara biaya yang dibayarkan dengan biaya yang telah ditetapkan, (12) Kepastian jadwal pelayanan, yaitu pelaksanaan waktu pelayanan, sesuai dengan ketentuan yang telah ditetapkan,

Kenyamanan lingkungan, yaitu kondisi sarana dan prasarana pelayanan yang bersih, rapi, dan teratur sehingga dapat memberikan rasa nyaman kepada penerima pelayanan, (14) Keamanan pelayanan, yaitu terjaminnya tingkat keamanan lingkungan unit penyelenggara pelayanan ataupun sarana yang digunakan, sehingga masyarakat merasa tenang untuk mendapatkan pelayanan terhadap resiko-resiko yang diakibatkan dari pelaksanaan pelayanan.

Penyelenggaraan pelayanan publik jasa transportasi yang diberikan oleh pemerintah dianggap belum efektif dan efesien. Hal ini sejalan dengan apa yang dikatakan Tamin dalam Situmeang (2008:2) 
karena ketidaksesuaian antara transport demand (permintaan akan transportasi) dan transport supplay (ketersediaan untuk mengantisipasi kebutuhan pergerakan) ataupun faktorfaktor yang relevan lainnya.

Sesuai dengan Peraturan Pemerintah RI No. 31 tahun 2002 tentang Perum Damri. Perum damri merupakan salah satu perusahaan umum yang didirikan oleh negara yang diberi wewenang sebagai penyelenggara pemberi layanan jasa angkutan umum, penumpang, dan barang diatas jalan dengan tujuan mengusahkan dan mengembangkan pelayanan angkutan penumpang dan barang diatas jalan dengan kendaraan bermotor untuk menunjang pembangunan negara dan bangsa dalam rangka meningkatkan ketahanan nasional dan mencapai masyarakat yang adil dan makmur material dan spiritual berdasarkan Pancasila.

Perum Damri sebagai pelayan jasa transportasi publik yang dimiliki oleh Negara berusaha untuk memberikan pelayanan yang memuaskan kepada para pengguna maupun pelanggan bus Damri. Jasa transportasi erat hubungannya dengan kepuasan masyarakat, serta tidak terlepas dari kualitas pelayanan jasa terutama menggunakan angkutan umum.

Penerapan sistem angkutan umum yang cepat dan efisien sehingga masyarakat lebih tertarik dengan angkutan umum. Upaya tersebut dapat menekan kenaikan jumlah kendaraan pribadi yang dari tahun ke tahun selalu meningkat. Hal ini sesuai dengan data Badan Pusat Statistik (BPS) Sulawesi-selatan tahun 2015 bahwa jumlah kendaraan bermotor kabupaten/ kota dan jenis kendaraan provinsi Sulawesi-selatan terdiri dari mobil penumpang 269.610 unit, bus 24.022 unit, mobil barang 129.972 dan sepeda motor 2.513.520 unit. Disamping itu, dalam 3 (tiga) tahun terakhir ini jumlah kendaraan pada tahun 2012 sebanyak 2.593.413, pada tahun 2013 sebanyak 2.673.725 unit dan pada tahun 2014 sebanyak 2.938 .193 unit. Data ini menunjukkan bahwa jumlah kendaraan bermotor di Sulawesiselatan mengalami peningkatan dari tahun ke tahun. 
Bus Rapid Transit (BRT) yang pertama dioperasikan di Indonesia yaitu Bus Rapid Transit (BRT) dengan nama Trans Jakarta pada tahun 2004, kemudian disusul oleh beberapa kota lainnya seperti Semarang, Yogyakarta, Surabaya, Bogor, Palembang. Pada tahun 2013 pemerintah Sulawesi-selatan merealisasiakan Bus Rapid Transit dengan sebutan Trans Maminasata dengan rencana melintasi beberapa daerah yakni Makassar, Maros, Gowa, dan Takalar. Sehingga melalui pelayanan BRT Maminasata ini diharapkan mampu menjadi solusi dalam hal menangani kemacetan di daerah tersebut dan didukung oleh stakeholder yang saling berkaitan satu dengan yang lainnya. Akan tetapi masyarakat masih kurang melirik angkutan umum tersebut dengan berbagai alasan.

Menurut Dwiyanto (2011: 18) ada beberapa kriteria yang dapat dikategorikan pelayanan publik. Kriteria pertama yaitu barang dan jasa yang memiliki eksternalitas tinggi. Kriteria kedua yaitu tujuan dari penyediaan barang dan jasa.
Pelayanan publik tidak terlepas dari namanya pemerintah, pemerintah memiliki fungsi yang sangat berpengaruh pada tingkat pelayanan publik. Sinambela (2011: 6) mempertegas bahwa pelayanan adalah kualitas pelayanan birokrat terhadap masyarakat.

Menurut Wright (2002: 1) dalam modulnya menyebutkan ciriciri utama sistem BRT meliputi: (1) Jalur bus terpisah, (2) Naik dan turun kendaraan yang cepat, (3) Stasiun dan terminal yang bersih, aman, dan nyaman, (4) Penarikan ongkos sebelum berangkat yang efisien, (5) Penandaan yang jelas dan mudah dikenali, dan tampilan informasi yang serta merta (real-time), (6) Prioritas angkutan dipersimpangan, (7) Integrasi moda di stasiun dan terminal, (8) Teknologi bus yang bersih, (9) Identitas pemasaran yang canggih, (10) Layanan pelanggan yang sangat baik.

Fitzsimmons dan fitzsimmons dalam Sinambela (2011:7) berpendapat terdapat lima indikator pelayanan publik, yaitu reliability yang ditandai pemberian pelayanan yang tepat dan benar; tangible yang 
ditandai dengan penyediaan yang memadai sumber daya manusia dan sumber daya lainya; responsiveness, yang ditandai dengan keinginan melayani konsumen dengan cepat; assurance, yang di tandai tingkat perhatian terhadap etika dan moral dalam memberikan pelayanan, dan empaty, yang di tandai dengan tingkat kemauan untuk mengetahui keinginan dan kebutuhan konsumen.

\section{METODE PENELITIAN}

Penelitian ini direncanakan selama kurang lebih 2 (dua) bulan setelah seminar proposal. Penlitian ini dilaksanakan di Bus Rapid Transit (BRT) pada beberapa koridor yang telah difungsikan di kota Makassar. Jenis penelitian yang digunakan dalam penelitian adalah penelitian deskriptif kuantitatif. Tipe penelitian yang digunakan dalam penelitian ini adalah penelitian observasional (non-eksperimen) dengan pendekatan cross section yang menjelaskan hubungan antara dua variabel yaitu kualitas pelayanan dengan kepuasan masyarakat pengguna Bus Rapid Transit (BRT) Maminasata.

Adapun populasi dalam penelitian ini adalah 561 penumpang dan sampel penelitian yaitu 101 orang. Adapun teknik pengumpulan data dalam penelitian ini yaitu observasi, angket dan dokumentasi. Sebelum data dianalisis, angket yang digunakan dalam penelitian ini dilakukan pengujian yaitu uji validitas dan uji reliabilitas dengan perhitungan SPSS.

Adapun kategori data yang telah diklasifikasikan berdasarkan interval kategori tersebut akan diuraikan pada tabel sebagai berikut:

Tabel 3.1 Interval Koefisien Korelasi Nilai r

\begin{tabular}{|c|c|}
\hline Interval Koefisien & Tingkat Hubungan \\
\hline $0,80-1,000$ & Sangat kuat \\
$0,60-0,799$ & Kuat \\
$0,40-0,599$ & Sedang \\
\hline
\end{tabular}




\begin{tabular}{|c|c|}
\hline $0,20-0,399$ & Rendah \\
$0,00-0,199$ & Sangat rendah \\
\hline
\end{tabular}

\section{HASIL DAN PEMBAHASAN}

Bus Rapid Transit (BRT)

Maminasata merupakan angkutan massal perkotaan di Sulawesi Selatan yang melintasi beberapa daerah yakni Kota Makassar, Kabupaten Maros, Kabupaten Gowa dan Kabupaten Takalar. Maminasata merupakan singkatan dari Makassar (Ibukota Kota Makassar), Maros (Ibukota Kabupaten Maros), Sungguminasa (Ibukota Kabupaten Gowa) dan Takalar (Ibukota Takalar).

Bus Rapid Transit (BRT) Maminasata pertama kali diresmikan untuk beroperasi di koridor II dengan tipe Mini Bus sebanyak 7 Unit yang berkapasitas 33 penumpang pada tahun 2014. Pada tahun 2015, Pemerintah Provinsi Sulawesi Selatan sebagai pemegang otoritas BRT Maminasata mengganti tipe Mini Bus tersebut menjadi Bus Mercedez benz 6000 cc. kapasitas penumpangnya sebanyak 60 orang dengan rincian 34 orang duduk termasuk 8 kursi prioritas dan 26 pasang pegangan untuk orang berdiri. Saat ini, jumlah BRT Maminasata yang tersedia sebanyak 30 Unit yang didatangkan secara bertahap. Pada tahun 2015 sebanyak 15 Unit dan pada tahun 2016 sebanyak 15 Unit.

Rute Bus Rapid Transit (BRT) Maminasata menunjukkan bahwa jumlah koridor yang beroperasi sampai saat ini sebanyak 3 (tiga) koridor yaitu koridor II, III dan IV. Tiga koridor ini dukung dengan adanya halte yang tersebar di berbagai tempat yaitu sebanyak 36 titik. Hal ini dapat kita lihat pada koridor II dan III, pada hari kerja hari senin sampai hari jumat jumlah bus yang beroperasi yaitu 7 sampai 8 bus/ hari dan setiap armada bus beroperasi 6-7 kali rit. Sedangkan pada hari weekend (Sabtu-Ahad) mengalami penambahan armada bus yaitu 2 sampai 4 bus sehingga jumlah bus yang beroperasi yaitu mencapai 10 sampai 12 bus. Perbedaan yang sangat jauh terlihat pada koridor IV, jumlah bus yang 
beroperasi setiap harinya (SeninAhad) yaitu hanya 1 armada bus. Hal ini disebabkan oleh sangat rendahnya minat masyarakat menggunakan $\mathrm{Bus}$
Rapid Transit (BRT) Maminasata pada koridor ini.

\section{Kualitas Pelayanan Bus Rapid} Transit (BRT) Maminasata

Hasil tanggapan terhadap reliability (kehandalan) dapat dijelaskan pada tabel berikut ini:

Tabel 4.6 Indeks tanggapan responden mengenai reliability (kehandalan)

\begin{tabular}{|l|l|l|l|l|l|l|l|l|l|}
\hline No. & \multicolumn{1}{|c|}{ Indikator } & \multicolumn{3}{|c|}{ Skor } & Jml & Indeks & Kriteria \\
\cline { 3 - 8 } & & SS & S & RR & TS & STS & & & \\
\hline 1. & $\begin{array}{l}\text { Petugas ramah } \\
\text { dalam memberikan } \\
\text { informasi pelayanan } \\
\text { Bus Rapid Transit } \\
\text { (BRT) Maminasata. }\end{array}$ & 30 & 68 & 1 & 2 & & 101 & $\begin{array}{l}84.95 \\
\%\end{array}$ & $\begin{array}{l}\text { Sangat } \\
\text { Berkuali } \\
\text { tas }\end{array}$ \\
\hline 2. & $\begin{array}{l}\text { Petugas memberikan } \\
\text { pelayanan sesuai } \\
\text { dengan prosedur Bus } \\
\text { Rapid Transit (BRT) } \\
\text { Maminasata. }\end{array}$ & 22 & 66 & 9 & & & 101 & $\begin{array}{l}77.42 \\
\%\end{array}$ & $\begin{array}{l}\text { Sangat } \\
\text { Berkuali } \\
\text { tas }\end{array}$ \\
\hline 3. & $\begin{array}{l}\text { Petugas } \\
\text { mempermudah } \\
\text { pengguna untuk } \\
\text { menggunakan Bus } \\
\text { Rapid Transit (BRT) } \\
\text { Maminasata. }\end{array}$ & 32 & 63 & 6 & & & 101 & $\begin{array}{l}85.14 \\
\%\end{array}$ & $\begin{array}{l}\text { Berkuali } \\
\text { tas }\end{array}$ \\
\hline 4. & $\begin{array}{l}\text { Bus Rapid Transit } \\
\text { (BRT) Maminasata } \\
\text { tepat waktu } \\
\text { mengenai } \\
\text { kedatangan dan } \\
\text { keberangkatannya. }\end{array}$ & 6 & 36 & 40 & 11 & 8 & 101 & 64.15 & $\begin{array}{l}\text { Berkuali } \\
\text { tas }\end{array}$ \\
\hline
\end{tabular}

Perhitungan indeks tanggapan responden mengenai reliability (kehandalan) adalah sebagai berikut:

(1) Indikator 1: Nilai indeks $\%=$ $429 / 505 \times 100=84.95$
(2) Indikator 2Nilai indeks $\%=$ $391 / 505 \times 10=77.42$

(3) Indikator 3 Nilai indeks $\%=$ $430 / 505 \times 100=85.14$

(4) Indikator 4Nilai indeks $\%=$ $324 / 505 \times 100=64.15$ 
(5) Nilai $(84.95+77.42+85.14+64.14) \quad / \quad 4=$ $77.91 \%$
Reliability (kehandalan) ( $\left.\mathrm{X}_{1}\right)$

Indeks $\quad=$

Hasil tanggapan terhadap tangible (bukti fisik) dapat dijelaskan pada tabel berikut ini:

Tabel 4.7 Indeks tanggapan responden mengenai tangible (bukti fisik)

\begin{tabular}{|l|l|l|l|l|l|l|l|l|l|}
\hline No. & \multicolumn{1}{|c|}{ Indikator } & \multicolumn{5}{|c|}{ Skor } & Jml & Indeks & Kriteria \\
\cline { 3 - 9 } 1. & $\begin{array}{l}\text { Ruang tunggu (halte) } \\
\text { Bus Rapid Transit } \\
\text { (BRT) Maminasata } \\
\text { bersih dan bagus. }\end{array}$ & 16 & 45 & 25 & 12 & 3 & 101 & $\begin{array}{l}71.28 \\
\%\end{array}$ & $\begin{array}{l}\text { Berkuali } \\
\text { tas }\end{array}$ \\
\hline 2. & $\begin{array}{l}\text { Jumlah halte Bus } \\
\text { Rapid Transit (BRT) } \\
\text { Maminasata memadai } \\
\text { dan mudah diakses. }\end{array}$ & 19 & 46 & 19 & 14 & 3 & 101 & $\begin{array}{l}72.67 \\
\%\end{array}$ & $\begin{array}{l}\text { Berkuali } \\
\text { tas }\end{array}$ \\
\hline 3. & $\begin{array}{l}\text { Jumlah Bus Rapid } \\
\text { Transit (BRT) } \\
\text { Maminasata setiap } \\
\text { koridor memadai. }\end{array}$ & 10 & 55 & 27 & 9 & & 101 & $\begin{array}{l}76.63 \\
\%\end{array}$ & $\begin{array}{l}\text { Berkuali } \\
\text { tas }\end{array}$ \\
\hline
\end{tabular}

Perhitungan indeks tanggapan responden mengenai tangible (bukti fisik) adalah sebagai berikut:

(1) Indikator 1: Nilai indeks $\%=$ $360 / 505 \times 100=71.28$

(2) Indikator 2: Nilai indeks $\%=$ $367 / 505 \times 100=72.67$
(3) Indikator 3: Nilai indeks $\%=$ $387 / 505 \times 100=76.63$

(4) Tangible (bukti fisik) $\left(\mathrm{X}_{2}\right)$ : Nilai indeks $=(71.28+72.67+76.63) /$ $3=73.52 \%$

Hasil tanggapan terhadap responsiveness (daya tanggap) dapat dijelaskan pada tabel berikut ini:

Tabel 4.8 Indeks tanggapan responden mengenai responsivenees (daya tanggap)

\begin{tabular}{|l|l|l|l|l|l|l|l|l|l|}
\hline No. & \multicolumn{1}{|c|}{ Indikator } & \multicolumn{5}{|c|}{ Skor } & Jml & Indeks & Kriteria \\
\cline { 3 - 8 } & & SS & S & RR & TS & STS & & & \\
\hline 1. & $\begin{array}{l}\text { Petugas ramah dalam } \\
\text { memberikan } \\
\text { pelayanan terhadap } \\
\text { keluhan pengguna } \\
\text { Bus Rapid Transit } \\
\text { (BRT) Maminasata. }\end{array}$ & 17 & 66 & 15 & 3 & & 101 & $\begin{array}{l}79.20 \\
\%\end{array}$ & $\begin{array}{l}\text { Berkuali } \\
\text { tas }\end{array}$ \\
\hline
\end{tabular}


Kolaborasi : Jurnal Administrasi Publik, Agustus 2017 Volume 3 Nomor 2

\begin{tabular}{|l|l|l|l|l|l|l|l|l|l|}
\hline 2. & $\begin{array}{l}\text { Petugas memberikan } \\
\text { perhatian yang bagus } \\
\text { terhadap saran } \\
\text { pengguna Bus Rapid } \\
\text { Transit (BRT) } \\
\text { Maminasata. }\end{array}$ & 12 & 68 & 20 & & 1 & 101 & $\begin{array}{l}77.82 \\
\%\end{array}$ & $\begin{array}{l}\text { Berkuali } \\
\text { tas }\end{array}$ \\
\hline 3. & $\begin{array}{l}\text { Petugas } \\
\text { melakukan perbaikan } \\
\text { dengan cepat dari } \\
\text { berbagai kritikan } \\
\text { pengguna Bus Rapid } \\
\text { Transit (BRT) } \\
\text { Maminasata }\end{array}$ & 7 & 44 & 47 & 3 & & 101 & $\begin{array}{l}70.89 \\
\%\end{array}$ & $\begin{array}{l}\text { Berkuali } \\
\text { tas }\end{array}$ \\
\hline
\end{tabular}

tanggapan responden mengenai 358/505 x $100=70.89$

responsivenees (daya tanggap)

(4) Responsivenees

(daya

adalah sebagai berikut:

(1) Indikator 1: Nilai indeks \% = tanggap) $\left(\mathrm{X}_{3}\right)$ Nilai indeks $=$ $400 / 505 \times 100=79.20$

$(79.20+77.82+70.89) / 3=75.97$

(2) Indikator 2: Nilai indeks $\%=$

Hasil tanggapan terhadap $393 / 505 \times 100=77.82$ assurance (jaminan) dapat dijelaskan pada tabel berikut ini:

Tabel 4.9 Indeks tanggapan responden mengenai assurance (jaminan)

\begin{tabular}{|c|c|c|c|c|c|c|c|c|c|}
\hline \multirow[t]{2}{*}{ No. } & \multirow[t]{2}{*}{ Indikator } & \multicolumn{5}{|c|}{ Skor } & \multirow[t]{2}{*}{ Jml } & \multirow[t]{2}{*}{ Indeks } & \multirow[t]{2}{*}{ Kriteria } \\
\hline & & SS & $\mathrm{S}$ & RR & TS & STS & & & \\
\hline 1. & $\begin{array}{l}\text { Petugas menagih } \\
\text { pembayaran sesuai } \\
\text { harga yang tertera } \\
\text { pada karcis Bus Rapid } \\
\text { Transit (BRT) } \\
\text { Maminasata. }\end{array}$ & 24 & 41 & 18 & 14 & 4 & 101 & $73.2 \%$ & $\begin{array}{l}\text { Berkuali } \\
\text { tas }\end{array}$ \\
\hline 2. & $\begin{array}{l}\text { Jadwal kedatangan } \\
\text { Bus Rapid Transit } \\
\text { (BRT) Maminasata } \\
\text { teratur. }\end{array}$ & 6 & 43 & 33 & 16 & 3 & 101 & 66.53 & $\begin{array}{l}\text { Berkuali } \\
\text { tas }\end{array}$ \\
\hline 3. & $\begin{array}{l}\text { Loket pelayanan } \\
\text { pembelian tiket } \\
\text { tersedia di berbagai } \\
\text { tempat yang dilalui } \\
\text { Bus Rapid Transit } \\
\text { (BRT) Maminasata. }\end{array}$ & 13 & 31 & 32 & 13 & 12 & 101 & 63.96 & $\begin{array}{l}\text { Berkuali } \\
\text { tas }\end{array}$ \\
\hline
\end{tabular}


Perhitungan indeks (3) Indikator 3: Nilai indeks $\%=$ tanggapan responden mengenai $323 / 505 \times 100=63.96$

assurance (jaminan) adalah sebagai berikut:

(1) Indikator 1: Nilai indeks $\%=$

(4) Assurance (jaminan) $\left(\mathrm{X}_{4}\right)$ : $370 / 505 \times 100=73.26$

(2) Indikator 2: Nilai indeks $\%=$ $336 / 505 \times 100=66.53$ Nilai indeks $=(73.26+66.53+63.96) /$ $3=67.91 \%$

Hasil tanggapan terhadap emphaty (empati) dapat dijelaskan pada tabel berikut ini:

Tabel 4.10 Indeks tanggapan responden mengenai empathy (empati)

\begin{tabular}{|c|c|c|c|c|c|c|c|c|c|}
\hline \multirow[t]{2}{*}{ No. } & \multirow[t]{2}{*}{ Indikator } & \multicolumn{5}{|c|}{ Skor } & \multirow[t]{2}{*}{$\mathrm{Jml}$} & \multirow[t]{2}{*}{ Indeks } & \multirow[t]{2}{*}{ Kriteria } \\
\hline & & SS & $\mathrm{S}$ & RR & TS & STS & & & \\
\hline 1. & $\begin{array}{l}\text { Petugas memberikan } \\
\text { perhatian secara } \\
\text { individual saat } \\
\text { menggunakan Bus } \\
\text { Rapid Transit (BRT) } \\
\text { Maminasata. }\end{array}$ & 12 & 55 & 20 & 13 & 1 & 101 & $\begin{array}{l}72.67 \\
\%\end{array}$ & $\begin{array}{l}\text { Berkuali } \\
\text { tas }\end{array}$ \\
\hline 2. & $\begin{array}{l}\text { Petugas memberikan } \\
\text { rasa aman dan } \\
\text { nyaman pada saat } \\
\text { berada dalam Bus } \\
\text { Rapid Transit (BRT) } \\
\text { Maminasata. }\end{array}$ & 19 & 71 & 9 & 2 & & 101 & $\begin{array}{l}81.18 \\
\%\end{array}$ & $\begin{array}{l}\text { Sangat } \\
\text { Berkuali } \\
\text { tas }\end{array}$ \\
\hline 3. & $\begin{array}{l}\text { Petugas selalu } \\
\text { bersikap sopan } \\
\text { dalam memberikan } \\
\text { pelayanan Bus } \\
\text { Rapid Transit (BRT) } \\
\text { Maminasata kepada } \\
\text { anda. }\end{array}$ & 28 & 70 & 3 & & & 101 & 84.95 & $\begin{array}{l}\text { Sangat } \\
\text { Berkuali } \\
\text { tas }\end{array}$ \\
\hline 4. & $\begin{array}{l}\text { Sikap sabar petugas } \\
\text { Bus Rapid Transit } \\
\text { (BRT) Maminasata } \\
\text { (Pengemudi \& } \\
\text { Kondektur) dalam } \\
\text { melayani } \\
\text { penumpang. }\end{array}$ & 21 & 70 & 10 & & & 101 & 82.17 & $\begin{array}{l}\text { Sangat } \\
\text { Berkuali } \\
\text { tas }\end{array}$ \\
\hline
\end{tabular}

Perhitungan indeks emphaty (empati) adalah sebagai tanggapan responden mengenai berikut: 
(1) Indikator 1: Nilai indeks $\%=$ $367 / 505 \times 100=72.67$

(2) Indikator 2: Nilai indeks $\%=$ $410505 \times 100=81.18$

(3) Indikator 3: Nilai indeks $\%=$ $429 / 505 \times 100=84.95$

(4) Indikator 4: Nilai indeks $\%=$ $415 / 505 \times 100=82.17$

(5) Empathy (empati) $\left(\mathrm{X}_{5}\right)$ : Nilai indeks $=(72.67+81.18+84.95+82.17)$ / $4=80.24 \%$

\section{Berdasarkan tanggapan} responden di atas,indikator-indikator dari kualitas pelayanan yang digunakan seperti: reliability dengan nilai 77.91, tangible 73.52, responsiveness 75.97 , assurance 67.91, dan empathy 80.24. Sehingga nilai rata-rata dari kelima indikator kualitas pelayanan yaitu mencapai 75.51\%. Dari hasil ini, dapat disimpulkan bahwa pelayanan yang diberikan oleh Perum Damri padaBus Rapid Transit (BRT) Maminasata berkualitas.

\section{Kepuasan Masyarakat Pengguna}

Bus Rapid Transit (BRT)

Maminsata

Hasil tanggapan terhadap keterpakaian dapat dijelaskan pada tabel berikut ini:

Tabel 4.11 Indeks tanggapan responden mengenai keterpakaian

\begin{tabular}{|c|c|c|c|c|c|c|c|c|c|}
\hline \multirow[t]{2}{*}{ No. } & \multirow[t]{2}{*}{ Indikator } & \multicolumn{5}{|c|}{ Skor } & \multirow[t]{2}{*}{$\mathrm{Jml}$} & \multirow[t]{2}{*}{ Indeks } & \multirow[t]{2}{*}{ Kriteria } \\
\hline & & SS & $\mathrm{S}$ & RR & $\mathrm{TS}$ & STS & & & \\
\hline 1. & $\begin{array}{l}\text { Saya merasa puas } \\
\text { mengenai jadwal } \\
\text { kedatangan dan } \\
\text { keberangkatan Bus } \\
\text { Rapid Transit (BRT) } \\
\text { Maminasata sangat } \\
\text { jelas dan tepat waktu. }\end{array}$ & 8 & 41 & 35 & 13 & 4 & 101 & $\begin{array}{l}67.12 \\
\%\end{array}$ & Puas \\
\hline 2. & $\begin{array}{l}\text { Saya merasa puas atas } \\
\text { kedisiplinan dan } \\
\text { tanggung jawab } \\
\text { petugas Bus Rapid } \\
\text { Transit (BRT) } \\
\text { Maminasata. }\end{array}$ & 12 & 67 & 20 & 2 & & 101 & $\begin{array}{l}77.62 \\
\%\end{array}$ & Puas \\
\hline 3. & $\begin{array}{l}\text { Saya merasa puas atas } \\
\text { kemampuan petugas } \\
\text { Bus Rapid Transit } \\
\text { (BRT) Maminasata } \\
\text { dalam memberikan } \\
\text { pelayanan. }\end{array}$ & 12 & 75 & 14 & & & 101 & $\begin{array}{l}79.60 \\
\%\end{array}$ & Puas \\
\hline
\end{tabular}




\begin{tabular}{|l|l|l|l|l|l|l|l|l|l|}
\hline 4. & $\begin{array}{l}\text { Saya akan selalu } \\
\text { menggunakan Bus } \\
\text { Rapid Transit (BRT) } \\
\text { Maminasata }\end{array}$ & 26 & 55 & 15 & 4 & 1 & 101 & $80 \%$ & $\begin{array}{l}\text { Sangat } \\
\text { Puas }\end{array}$ \\
\hline
\end{tabular}

Perhitungan indeks tanggapan responden mengenai keterpakaian adalah sebagai berikut:

(1) Indikator 1: Nilai indeks \% = $339 / 505 \times 100=67.12$

(2) Indikator 2: Nilai indeks $\%=$ $392 / 505 \times 100=77.62$

(3) Indikator 3: Nilai indeks \% = $402 / 505 \times 100=79.60$

(4) Indikator 4: Nilai indeks $\%=$ $404 / 505 \times 100=80$

Tabel 4.12 Indeks tanggapan responden mengenai senang

\begin{tabular}{|c|c|c|c|c|c|c|c|c|c|}
\hline \multirow[t]{2}{*}{ No. } & \multirow[t]{2}{*}{ Indikator } & \multicolumn{5}{|c|}{ Skor } & \multirow[t]{2}{*}{ Jml } & \multirow[t]{2}{*}{ Indeks } & \multirow[t]{2}{*}{ Kriteria } \\
\hline & & SS & $\mathrm{S}$ & RR & TS & STS & & & \\
\hline 1. & $\begin{array}{l}\text { Saya merasa senang } \\
\text { dengan laju kecepatan } \\
\text { Bus Rapid Transit } \\
\text { (BRT) Maminasata. }\end{array}$ & 28 & 65 & 4 & 2 & 2 & 101 & $\begin{array}{l}82.77 \\
\%\end{array}$ & $\begin{array}{l}\text { Sangat } \\
\text { Puas }\end{array}$ \\
\hline 2. & $\begin{array}{l}\text { Saya merasa senang } \\
\text { dengan keramahan } \\
\text { petugas Bus Rapid } \\
\text { Transit (BRT) } \\
\text { Maminasata. }\end{array}$ & 22 & 75 & 3 & 1 & & 101 & $\begin{array}{l}64.95 \\
\%\end{array}$ & Puas \\
\hline 3. & $\begin{array}{lr}\text { Saya merasa } & \text { senang } \\
\text { dengan tarif } & \text { Bus } \\
\text { Rapid } \\
\text { Transit } & \text { (BRT) } \\
\text { Maminasata } & \text { yang } \\
\text { murah. } & \end{array}$ & 45 & 50 & 6 & & & 101 & $\begin{array}{l}87.72 \\
\%\end{array}$ & $\begin{array}{l}\text { Sangat } \\
\text { Puas }\end{array}$ \\
\hline
\end{tabular}


Kolaborasi : Jurnal Administrasi Publik, Agustus 2017 Volume 3 Nomor 2

Perhitungan indeks tanggapan responden mengenai senang adalah sebagai berikut:

(1) Indikator 1: Nilai indeks $\%=$ $418 / 505 \times 100=82.77$

(2) Indikator 2: Nilai indeks $\%=$ $328 / 505 \times 100=64.95$
(3) Indikator 3: Nilai indeks $\%=$ $448 / 505 \times 100=87.72$

(4) Senang $\left(\mathrm{Y}_{2}\right)$ : Nilai Indeks = $(82.77+64.95+87.72) / 3=78.84$

Hasil tanggapan responden mengenai merekomendasikan dapat dijelaskan pada tabel berikut ini:

Tabel 4.13 Indeks tanggapan responden mengenai merekomendasikan.

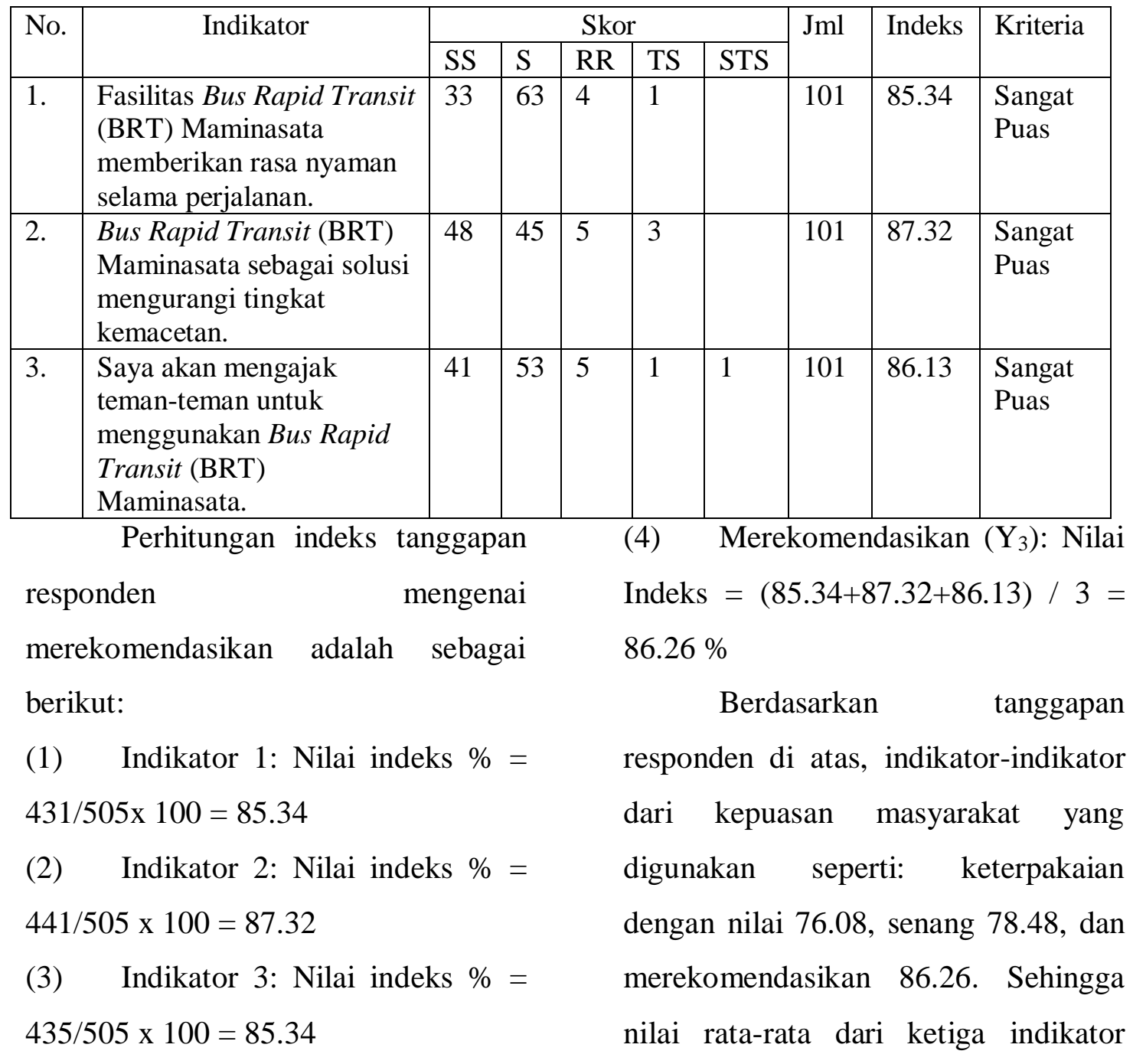


kepuasan masyarakat yaitu mencapai 86.26.Dari hasil ini, dapat disimpulkan bahwa masyarakat merasakan sangat puas dalam menggunakan Bus Rapid Transit (BRT) Maminasata.

\section{Hubungan Kualitas Pelayanan dengan Kepuasan Masyarakat Pengguna Bus Rapid Transit (BRT) Maminasata}

\section{Analisis Deskriptif}

Tabel 4.17. Analisis Deskriptif

\begin{tabular}{|l|r|r|r|r|r|}
\hline & N & Minimum & Maximum & Mean & Std. Deviation \\
\hline Kualitas Pelayanan & 101 & 44 & 82 & 64.46 & 7.008 \\
Kepuasan Masyarakat & 101 & 29 & 50 & 40.84 & 3.846 \\
Valid N (listwise) & 101 & & & & \\
\hline
\end{tabular}

Output analisis Descriptif

Dari output di atas dapat diketahui bahwa variabel $\mathrm{x}$ dengan jumlah data (N) sebanyak 101 mempunyai nilai rata-rata 64,46 ; dengan nilai minimum 44 dan maksimal 82, sedangkan standar deviasi sebesar 7,008. Dan variabel y dengan jumlah data $(\mathrm{N})$ sebanyak 101 mempunyai rata-rata sebesar 40,84; dengan nilai minimum 29 dan maksimal 50 sedangkan standar deviasi sebesar 3,846.

\section{Analisis Statistik Inferensial}

\section{Korelasi Product Moment:}

Uji korelasi dalam penelitian ini digunakan untuk mengetahui tingkat hubungan dalam penelitian ini. Untuk lebih jelasnya dapat dijelaskan dalam pada tabel berikut: 
Tabel 4. 18. Uji korelasi

\begin{tabular}{|ll|r|r|}
\hline \multicolumn{1}{c|}{ Correlations } \\
\hline Kualitas Pelayanan & Kualitas Pelayanan & Kepuasan Masyarakat \\
& Pearson Correlation & 1 & .606 \\
& Sig. (2-tailed) & & .000 \\
& $\mathrm{~N}$ & 101 & 101 \\
\hline Kepuasan Masyarakat & Pearson Correlation & .606 & 1 \\
& Sig. (2-tailed) & .000 & \\
& $\mathrm{~N}$ & 101 & 101 \\
\hline
\end{tabular}

**. Correlation is significant at the 0.01 level (2-tailed).

Uji Hipotesis

$$
\begin{aligned}
& \text { df }=N-n r \\
& =101-2 \\
& =99
\end{aligned}
$$

Signifikan $=5 \%$

$$
\mathrm{Tt}=0.196
$$

Uji Hipotesis

$$
\begin{aligned}
& \mathrm{Rxy}>\mathrm{Tt} \\
& 0.606>0.196
\end{aligned}
$$

Dari output diketahui bahwa korelasi antara variabel kualitas pelayanan dengaan kepuasan masyarakat didapat nilai koefisien korelasi sebesar 0,606. Tanda positif menunjukkan bahwa hubungan yang tejadi adalah positif, artinya semakin tinggi kualitas pelayanan maka semakin tinggi kepuasan masyarakat.
Nilai 0,606 menunjukkan besarnya koefisien korelasi, dan dapat disimpulkan bahwa hubungan kuat karena berada pada rentang 0,6 0,799 .

Signifikansi didapat 0,00 artinya ada hubungan yang signifikan antara kualitas pelayanan dengan kepuasan masyarakat. Hal ini karena nilai 0,00 lebih kecil dari 0,05 . Sedangkan $\mathrm{N}=101$ menunjukkan data sebanyak 112.

(1) Menentukan hipotesis nol dan hipotesis alternatif

$\mathrm{H}_{0}$ : Tidak terdapat hubungan kualitas pelayanan dengan kepuasan masyarakat pengguna Bus Rapid Transit (BRT) Maminasata. 
Kolaborasi : Jurnal Administrasi Publik, Agustus 2017 Volume 3 Nomor 2

$\mathrm{H}_{\mathrm{a}}$ : Terdapat hubungan hubungan kualitas pelayanan dengan kepuasan masyarakat pengguna Bus Rapid Transit (BRT) Maminasata.

(2) Menentukan signifikansi. Dari output dapat diketahui signifikansi adalah 0,00

(3) Pengambilan

keputusan

Signifikansi > 0,05 jadi $\mathrm{H}_{0}$ diterima Signifikansi $\leq 0,05$ jadi $\mathrm{H}_{0}$ ditolak

(4) Kesimpulan: Dapat diketahui bahwa Signifikansi sebesar 0,00 lebih kecil dari 0,05 maka hipotesis nol ditolak ( $\mathrm{H}_{0}$ ditolak), kesimpulannya yaitu ada hubungan yang signifikan antara kualitas pelayanan dengan kepuasan masyarakat pengguna Bus Rapid Transit (BRT) Maminasta.

\section{KESIMPULAN}

Berdasarkan hasil penelitian maka dapat ditarik kesimpulan sebagai berikut:

Pelayanan yang diberikan oleh Perum Damri padaBus Rapid Transit (BRT) Maminasata berkualitas. Hal ini terlihat dari hasil tanggapan responden atas indikator-indikator dari kualitas pelayanan yang digunakan dalam penelitian ini seperti: reliability dengan nilai 77.91, tangible 73.52, responsiveness 75.97, assurance 67.91, dan empathy 80.24. Sehingga nilai rata-rata dari kelima indikator kualitas pelayanan yaitu mencapai 75.51 .

Masyarakat pengguna Bus Rapid Transit (BRT) Maminasata merasakan sangat puas atas pelayanan yang didapatkan. Hal ini terlihat dari hasil tanggapan responden atas indikator-indikator dari kepuasan masyarakat yang digunakan seperti: keterpakaian dengan nilai 76.08 , senang 78.48 , dan merekomendasikan 86.26. Sehingga nilai rata-rata dari ketiga indikator kepuasan masyarakat yaitu mencapai 90.27

Hubungan kualitas pelayanan dengan kepuasan masyarakat pengguna Bus Rapid Transit (BRT) Maminasata yaitu tergolong memiliki hubungan yang kuat. Hal ini dapat diketahui dari hasil uji korelasi product moment dengan menggunakan SPSS 16 yang mencapai angka 0.606 (hubungan kuat). 


\section{DAFTAR PUSTAKA}

Amalina, Camelia Hanifah. 2010. Hubungan antara Kepuasan Konsumen dan Kualitas Pelayanan dengan Loyalitas Konsumen pada Ritel Modern. Skripsi S1. Universitas Sebelas Maret: Surakarta.

Badan Pusat Statistik (BPS). 2015. Sulawesi-selatan dalam Angka 2015. Sulawesi-selatan.

Dwiyanto, Agus. 2011. Manajemen Pelayanan Publik: Peduli, Inklusif, dan Kolaboratif. Edisi Kedua. Yogyakarta: Gadjah Mada University Press.

Dahmiri. 2014. Analisa Kepuasan Masyarakat terhadap Kinerja Pelayanan Kantor Camat Kecamatan Sarolangun. Jurnal Studi Manajemen. Vol.8, No.2 Oktober 2014. Universitas Jambi.

Fitriani, Aprillia. 2014. Hubungan Kualitas Pelayanan terhadap Kepuasan Nasabah pada PT. Bank BRI Syariah KCP Rawamangun. Skripsi S1. Universitas Islam negeri Syarif Hidayatullah Jakarta: Jakarta.

Fardhani, Herentama. 2010. Analisis Faktor-faktor yang Mempengaruhi Kepuasan Masyarakat pada Pelayanan Badan Pelayanan Perizinan Terpadu Kota Semarang. Skripsi S1. Universitas Diponegoro: Semarang.

Tjiptono, F dan Gregorius, C. 2005. Service, Quality, and Satisfaction. Andi Offset: Yogyakarta.
Parasuraman, A. Valerie. 2001. (Diterjemahkan oleh Sutanto) Delivering Quality Service. The Free Press, New York. Situmeang, Poltak. 2008. Analisa

Kinerja Pelayanan Angkutan

Mobil Penumpang Umum

Antar Kota (Studi Kasus: Angkutan Umum Trayek Medan-Tarutung). Tugas Akhir S1. Universitas Sumatera Utara: Medan.

Peraturan Pemerintah Republik Indonesia tentang Perusahaan Umum (PERUM) DAMRI No. 31 tahun 2002 tentang Perum Damri.

Keputusan Menteri Pendayagunaan Aparatur Negara tentang Pedoman Umum Penyelenggaraan Pelayanan Publik, No. 63/ KEP/ M.PAN/ 7/ 2003.

Sinambela, Lijan Poltak. 2011. Reformasi Pelayanan Publik (Teori, Kebijakan, dan Implementasi). Jakarta: Bumi Aksara.

Wright, Lloyd. 2002. Modul 3b Angkutan Bus Cepat. TZ Verlagsgesellschaft $\mathrm{mbH}$ : Braunschweig 19, 64380 Roßdorf, Germany. 